\title{
'Formiguers', a historical system of soil fertilization (and biochar production?)
}

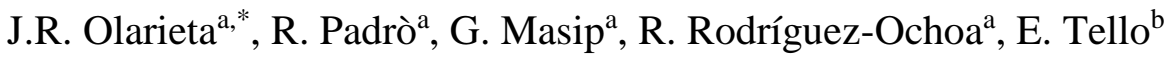 \\ a Departament de Medi Ambient i Ciències del Sòl. Universitat de Lleida. \\ Rovira Roure, 191. Lleida 25198. Spain \\ ${ }^{b}$ Departament d'Història i Institucions Econòmiques. Universitat de Barcelona. \\ Av. Diagonal 690. Barcelona 08034. Spain \\ * Corresponding author. Tel: 34-973702590; fax: 34-973702612. \\ e-mail: jramon.olarieta@macs.udl.cat
}

\begin{abstract}
'Formiguers' are structures similar to charcoal-kilns that were used to burn piles of biomass with a soil cover in order to produce fertilizers for agricultural plots. Their use was widespread in Spain up to the 1960s and similar structures are still in use in India and Bhutan. Our objective was to study the effects of the 'formiguer' on its soil cover in terms of changes in nutrient availability. We built an experimental $0.5 \mathrm{~m}^{3}$-'formiguer' with $68 \mathrm{~kg}$ of plant material with a $12 \%$ moisture content and $550 \mathrm{~kg}$ of soil with a $16 \%$ moisture content. The content of organic carbon and mineral nitrogen decreased in the soil cover as a result of burning. After aerobic incubation all samples had a similar content of mineral nitrogen. Exchangeable potassium and total and labile phosphorus increased after burning as a result of the soil cover mixing with the ashes of the biomass as the 'formiguer' collapsed during burning in the first two cases, while mineralization of organic compounds produced the increase in labile phosphorus. This input of nutrients for the agricultural plots occurs at a net loss of $0.4-2.5 \mathrm{Mg}$ organic C.ha ${ }^{-1}$. Very small amounts of charcoal were produced and this may be the reason for their low occurrence in soils today. Burning of 'formiguers' required the harvest of vegetation from a considerable forest area (10-25 ha per hectare of agricultural land) and represented a significant disturbance of these systems.
\end{abstract}




\section{Key words:}

land use; nitrogen; nutrient fluxes; organic carbon; phosphorus; potassium

\section{Introduction}

Pre-industrial agrarian systems relied on the import of materials from some land units of the system (forests, heathland, pastures) as fertilizers for the agricultural units (Entwistle et al., 2000; Christiansen, 2001). Understanding these fluxes helps explain not only the present patchiness of the landscape in terms of soil characteristics and vegetation development (Koerner et al., 1999; Woods, 2003; Fraterrigo et al., 2006), but also the (un)sustainability of the whole system in historical terms (Guzmán and González de Molina, 2009). Our work in five villages $(13,488$ ha) in the Vallès county (Catalunya, northeast Spain) shows that the agricultural sub-systems of the $19^{\text {th }}$ century depended to a significant extent on the imports of energy and matter from the forest and pasture subsystems (Cussó et al., 2006; Tello et al., 2008). And according to historical references, 'formiguers' were an important tool in the agricultural use of biomass from forest and shrubland.

'Formiguers' (term used in Catalan; the words 'hormiguero' or 'horniguero' are used in Spanish) are structures similar to charcoal kilns that were used up to the 1960s in many regions of Spain to produce a fertilizing material, both in humid and semiarid areas and for acid and calcareous soils (Baron de Alvalat, 1780; de Roxas, 1808; Masip, 2003; Miret, 2004). They were made up of piles of dried woody vegetation that were burnt under a soil cover (Figure 1) so that a slow and incomplete combustion was produced and the resulting material used as fertilizer and/or soil conditioner in agricultural fields. 'Formiguers' were built not only to dispose of the woody vegetation when a piece of forest 
was clear for agriculture but also specifically to improve agricultural soils. While in the former case all kinds of vegetation were burnt, only smaller branches and shrubs from forest or shrubland or material from pruning vineyards or olive trees were used in the latter. According to Mestre and Mestres (1949), 'formiguers' had a volume of $0.5 \mathrm{~m}^{3}$ when they were built every year, and about $2 \mathrm{~m}^{3}$ when they were used just in the first year of a vineyard or fruit-tree plantation.

\section{(Location of Figure 1)}

Mishra and Ramakrishnan (1983a, 1983b) describe a similar practice that is still used as part of the burning phase of the jhum system (shifting cultivation) in Meghalaya (India). In this case, undergrowth of shrubs and herbs and lower branches of pine trees (Pinus kesiya) are slashed, arranged in rows and left to dry before burning under a cover of soil. Crops are then sown on these rows. Kerkhoff and Sharma (2006) also describe this practice in Bhutan and the Arunachal Pradesh region of India, but they suggest its aim is to reduce nutrient losses in smoke.

In some other cases, the fertilizing material is not obtained from specifically-built structures (i.e. 'formiguers'), but is a by-product of charcoal production as only the bigger pieces obtained are suitable for sale and the finer material is used as fertilizer (Miret, 2004; Madari et al., 2003). This practice was widespread in the Amazon Basin where it has been partly responsible for the development of specific and highly-productive soils (the socalled 'terra preta' or Amazonian Dark Earth) (Woods, 2003).

Interest in these systems of biomass treatment is being renewed not only as a way of producing a soil fertilizer, but also as methods of carbon sequestration in soils and reduction of greenhouse gas emissions (Lehmann et al., 2006), although their efficiency in this respect is not free of debate (Wardle et al., 2008). 
A survey involving old farmers in the Priorat region (Catalunya, northeast Spain) (Masip, 2003) shows that 'formiguers' were historically appreciated both for their weedkilling and disinfectant effect on the soil cover and for their soil fertilizing properties. Temperatures reached in the soil cover of the 'formiguer' during burning vary between 30$40^{\circ} \mathrm{C}$ in the outer layer and over $300^{\circ} \mathrm{C}$ in the inner layer (Mestre and Mestres, 1949). The latter values would be lethal for most seeds and propagules (Dahlquist et al., 2007) and would therefore be an important tool for farmers when clearing a piece of forest for agriculture, as recognised in old documents (de Roxas, 1808). Similar temperatures may be reached in the soil under the 'formiguer' down to a depth of 1-2 cm (Giardina et al., 2000b).

The disinfectant effect of 'formiguers' on their soil cover would have been quite variable as a result of the wide range of temperatures obtained. In general, some soils would be sterilized at temperatures of $150^{\circ} \mathrm{C}$ (Badía and Martí, 2003b) and most at temperatures of $250-300^{\circ} \mathrm{C}$ (Serrasolses and Khanna, 1995; Badía and Martí, 2003b). 'Formiguers' would act as a surrogate to autoclaving, a process used to sterilize soils by heating under pressure in moist conditions (Serrasolses et al., 2008). Farmers interviewed by Masip (2003) strongly emphasized the importance of a moist soil cover of the 'formiguers'.

Traditionally the fertilizing effect of 'formiguers' has been linked to the ashes produced (Saguer and Garrabou, 1996). But the construction of 'formiguers' involves a high amount of labour and their interest to farmers could not be limited to some ashes that would have been obtained just as well from burning an uncovered pile of dry vegetation. A few farmers in the survey by Masip (2003) specifically mention the soil cover as the most important fertilizing product, and we therefore established as our hypothesis that 'formiguers' were specifically built to produce changes in the soil cover so as to improve its fertility and not just to produce ashes. 
High losses of nitrogen $(\mathrm{N})$ would be expected both from the burnt biomass and from the soil cover, as nitrate vaporizes at temperatures of $80^{\circ} \mathrm{C}$ and some amino acids at less than $200^{\circ} \mathrm{C}$ (Fisher and Binkley, 2000), but this gaseous $\mathrm{N}$ would have to pass through the moist soil cover where it might be partially recovered as ammonia.

Phosphorus $(\mathrm{P})$, on the other hand, is quite refractory and some oxides formed during burning will only volatilize at $360^{\circ} \mathrm{C}$ (Fisher and Binkley, 2000), a temperature which would hardly be reached even in the most exposed part of the soil cover of 'formiguers' (Mestre and Mestres, 1949). The situation would be similar for potassium hydroxide, which only vaporizes at temperatures over $350^{\circ} \mathrm{C}$, while calcium and magnesium oxides are stable at temperatures up to $2500{ }^{\circ} \mathrm{C}$ (Fisher and Binkley, 2000).

Ashes obtained from a 'formiguer' would thus be relatively rich in $\mathrm{P}$, calcium, magnesium, and potassium $(\mathrm{K})$. The latter three nutrients are not usually scarce in calcareous soils, but $\mathrm{K}$ is important in terms of controlling the loss of water by crops during dry periods. While the content of $\mathrm{P}$ in ashes may be high, a large proportion is in forms that are not readily available to plants (Carreira and Niell, 1995; Badía and Martí, 2003a). On the other hand, the application of plant ashes is beneficial for acid soils in order to increase the availability of basic cations and other nutrients such as P (Glaser et al., 2002). While basic soils are predominant in our study area, acid soils are very frequent in other areas in Catalunya and Spain.

Part of the fertilizing effect of 'formiguers' was historically assigned also to changes in the physical properties of the soil cover as a result of heating, with fine-textured soils becoming "lighter" (de Roxas, 1808; Matons, 1917-18; Masip, 2003), as sand-sized particles develop from the fusion of clay particles with increasing temperatures (Badía and Martí, 2003a).

'Formiguers' were therefore considered as an alternative to manure or synthetic fertilizers when these products were not available or their price was too high. Furthermore, 
such recommendation only extended to fine-textured soils or soils rich in organic matter, but not to coarse-textured soils or soils with gypsum (Baron de Alvalat, 1780; de Roxas, 1808; Matons, 1917-18). Unfortunately, no reason was provided for these recommendations. Mestre and Mestres (1949) proved that fertilizing with 'formiguers' increased the yield of wheat in comparison to unfertilized plots, and that in some cases its effect on yield was equivalent to that of chemical fertilizers (unspecified amount). De Roxas (1808) considered that one 'formiguer' was equivalent to $60 \mathrm{~kg}$ of manure.

But the controversy remained in relation to their profitability because of the high amounts of labour involved (Matons, 1917-18). The references about the actual number of 'formiguers' burnt provide quite variable figures. While some authors suggest that the optimum density to adequately fertilize an agricultural plot was about 1100 per hectare (de Roxas, 1808), the actual figures would have been closer to 700 (Baron de Alvalat, 1780) or as low as 260 per hectare (Roca, 2008). According to this author, 1 working-day was required to build 38-39 'formiguers' and, therefore, 7-20 working days were required for 260-700 'formiguers'.

Our objective in this study was to investigate the rationale behind the fertilizing effect 'formiguers' in terms of soil nutrients, and specifically whether there are significant changes in the soil cover of the 'formiguer' in terms of an enhanced mobilization of nutrients from soil organic matter.

\section{Materials and methods}

We built a 'formiguer' on an olive-tree orchard following the details collected by Masip (2003) from old farmers in the Priorat region (Tarragona), who describe it as a pile of woody vegetation with a diameter of $1.5 \mathrm{~m}$ and a height of $1.0 \mathrm{~m}$ and covered with soil. 
The volume, therefore, was about $0.6 \mathrm{~m}^{3}$ and thus represents the small type of 'formiguer' used for annual fertilization of crops (Mestre and Mestres, 1949).

Dry coarse woody material (small branches of P. halepensis, Quercus coccifera, Rosmarinus officinalis, and wild-growing Prunus dulcis and Olea europea) collected from a low-density Pinus halepensis forest located close to the orchard was placed at the bottom and finer branches on top. The material used was weighed before placing it in the pile and sampled to determine the dry matter content at $80^{\circ} \mathrm{C}$. This material was covered with large soil sods overlaid by finer pieces obtained from the top $5-10 \mathrm{~cm}$ of the mineral soil of the same forest plot. All the soil used was weighed. We used soil from a low-density forest plot because we would expect agricultural soils in the 19th century to have a higher organic matter content than present agricultural soils, and also because 'formiguers' were sometimes used in the conversion of forest to agricultural land. Another pile of similar woody material but without a soil cover was also burnt in order to compare its ashes with those obtained from the 'formiguer'.

Five samples weighing $0.5 \mathrm{~kg}$ each were taken from the soil cover of the formiguer before burning. A portion of each of these fresh samples was used to determine the moisture content, $\mathrm{N}$-nitrate (1:1 extraction in water and determination with Nitracheck@), and $\mathrm{N}$-ammonium (extraction with $1 \mathrm{M} \mathrm{KCl}$ ). Fresh samples were also incubated in aerobic conditions for 45 days at a temperature of $20^{\circ} \mathrm{C}$ maintaining the samples at field capacity. After this period they were analysed again for $\mathrm{N}$-nitrate and $\mathrm{N}$-ammonium.

Otherwise the samples were dried, sieved to $2 \mathrm{~mm}$, and analysed for organic carbon (Walkley-Black method), total N (Kjeldahl method), exchangeable K (extraction with ammonium acetate), total $\mathrm{P}$ (extraction with concentrated nitric-hydrocloric acid), labile $\mathrm{P}$ (extraction with $\mathrm{NaHCO}_{3}$ ), and inorganic (Ca-bound) phosphorus (extraction with $\mathrm{H}_{2} \mathrm{SO}_{4}$ 0.5M) (Ha et al., 2008). $\mathrm{P}$ was determined colorimetrically in all extracts. 
The 'formiguer' was left to burn for four days ('for a few days' according to our informants). After these four days the structure had collapsed. We took five $0.5 \mathrm{~kg}$-samples from the outer layer of the soil cover (top $5 \mathrm{~cm}$ of the soil cover not apparently in touch with charcoal or ashes) and another five from the inner cover (soil sods which were in contact with charcoal pieces). These samples were subject to the same treatments and analyses as those obtained before burning. There were almost no ashes resulting from combustion that could be sampled although the inner layer of soil cover showed signs of having mixed with them, possibly when the structure collapsed. Some char pieces were produced, less than $3 \mathrm{~kg}$, and three samples were taken for chemical analyses. These samples together with the five samples obtained from the ashes of the pile of woody material burnt without soil cover were analysed for organic matter (by loss on ignition at $550^{\circ} \mathrm{C}$ ), total nitrogen (Kjeldahl method), total phosphorus and potassium (extraction with concentrated $\mathrm{HCl}$ after ignition at $\left.550^{\circ} \mathrm{C}\right)$.

Results were analysed with the SAS statistical package, using the Generalized Linear Model Procedure to detect the effects among treatments and, if appropriate, Duncan's test for the separation of means with $\mathrm{p}=0.05$.

\section{Results}

The total amount of plant material burnt in the 'formiguer' was $68 \mathrm{~kg}$ with a moisture content of $12 \%$. The soil cover was made up of $550 \mathrm{~kg}$ with a moisture content of $16 \%$ and a loamy texture. This soil showed a strong reaction to $11 \% \mathrm{HCl}$ (calcium carbonate-equivalent content higher than 20\%) and a pH of 8.2. The other chemical fertility characteristics are shown in Table 1. Values are typical of forest soils in the area, except those for labile $\mathrm{P}$, which are relatively high. The OC content is in the upper half but still within the range of values of agricultural soils in the region. 
This soil cover of the 'formiguer' showed significant changes after burning. As shown in Table 1, mineral nitrogen, which includes both $\mathrm{N}-\mathrm{NO}_{3}$ and $\mathrm{N}-\mathrm{NH}_{4}$, and is an indicator of short-term available $\mathrm{N}$, dropped significantly from $7.0 \mathrm{mg} . \mathrm{kg}^{-1}$ to $1.4 \mathrm{mg} . \mathrm{kg}^{-1}$ in the samples taken from the outer layer and to undetectable levels in the inner layer. This decrease was the result of the disappearance of nitrate- $\mathrm{N}$ from the inner layer and its significant decrease in the outer layer of soil. Ammonia-N, on the other hand, increased significantly in the outer layer, but this increase did not fully compensate for the loss of nitrate, due to the relatively low levels of ammonia in comparison to nitrate in all compartments. Total $\mathrm{N}$ content was not significantly affected by burning but the mean values in both layers of the soil cover were lower than that of the soil before burning.

The behaviour of $\mathrm{P}$ was completely different from $\mathrm{N}$. Mean values for labile $\mathrm{P}$ were 4-9 times higher in the soil cover after burning, but differences were only statistically significant for the inner layer (Table 1). Similarly, inorganic P increased after burning by a factor of 8. In this case both the content in the inner and in the outer layer were significantly higher than the content in the soil before burning, but still the content in the inner layer doubled that of the outer layer. Total P significantly increased in the inner layer of soil after burning by more than $50 \%$ while there was no significant change in the outer layer.

Exchangeable $\mathrm{K}$ behaved in a similar way to $\mathrm{P}$, increasing significantly by over $300 \%$ in the inner layer of the soil cover after burning with no significant change in the outer layer.

On the other hand, organic carbon (OC) decreased significantly in the soil cover of the 'formiguer' after burning, with values in the inner layer reaching about $60 \%$ of those before heating, and a general decrease in the soil cover of about $33 \%$.

Samples incubated after burning, although initially depleted from mineral N, recovered to levels similar to those of soil samples not used as soil cover for the 
'formiguer', with nitrate-N comprising over $99 \%$ of the total mineral N. Net mineralization rates of $104 \mathrm{mg} \cdot \mathrm{kg}^{-1}$ were obtained for the latter samples while rates of $160 \mathrm{mg} \cdot \mathrm{kg}^{-1}$ and 77 mg.kg-1 were obtained for the outer and inner layers of the soil cover of the 'formiguer', respectively (Table 2).

The analysis of ashes obtained from the pile of woody material burnt without a soil cover showed that, compared to the mineral soil used to cover the 'formiguer', they were relatively rich in $\mathrm{P}$, but specially in $\mathrm{K}$ (Table 3 ). The charcoal pieces obtained in the 'formiguer', on the other hand, had a very high content of K, OC (over $950 \mathrm{~g}^{\mathrm{kg}} \mathrm{kg}^{-1}$ ), and N, which doubled that of the mineral soil.

\section{Discussion}

\subsection{Changes in the soil cover of the 'formiguer'}

The soil cover did not show any signs of rubefaction on visual inspection after burning, not even in the inner layer. We therefore suggest that the temperature in our 'formiguer' did not reach $300^{\circ} \mathrm{C}$ and that no significant losses of $\mathrm{K}$ or $\mathrm{P}$ took place from the soil cover. Historical references considered that this cover should not become 'red' in colour as this was a sign of overheating, and should instead have a 'black colour' (Baron de Alvalat, 1780).

We set as one of our hypotheses that the amount of labour involved in the 'formiguers' cannot be justified on the basis of the ashes obtained. In fact, almost no ashes were visible after burning the 'formiguer', or certainly not enough that may have been separated from the soil cover. Nevertheless, our results suggest that ashes must get mixed with the inner layer of the soil cover as the structure collapses during burning, and have significant effects on the chemical characteristics of this cover. This mixture would be the reason behind the increase in the total amount of $\mathrm{P}$ in the inner layer after burning the 'formiguer'. It would also account for the increase in exchangeable $\mathrm{K}$ because a significant 
fraction $(20-60 \%)$ of the amount of this cation added in the ashes is in water-soluble forms (Carreira and Niell, 1995).

But ashes cannot explain the increase in labile $\mathrm{P}$ in the outer layer of the soil, because this layer did not apparently mix with them, and can only partially explain the increase in the inner layer of the soil cover, because their amount was so small and because the water-soluble fraction may be only $3 \%$ of the total P added in the ashes (Carreira and Niell, 1995). The other process that may be involved in such increase in labile $\mathrm{P}$ would be the mineralization of organic $\mathrm{P}$ as a result of heating the soil in conditions similar to those of autoclaving (Romanyà et al., 1994; Badía and Martí, 2003a; Serrasolses et al., 2008).

This increase in labile $\mathrm{P}$ amounts to a minimum of $7-8 \mathrm{~kg} \mathrm{P}$ per hectare if we assume a density of 260 'formiguers' per hectare and an increase in the concentration of that form of $\mathrm{P}$ of $60 \mathrm{~g} \cdot \mathrm{kg}^{-1}$ (the difference between the concentration in the outer layer and that in the soil before burning). $\mathrm{P}$ availability has been shown to be an important variable for barley production in arid regions (Ayoubi et al., 2009), and responses to $\mathrm{P}$ application may be obtained at rates of 6-15 kg P.ha ${ }^{-1}$ (Valkama et al., 2009) as it also increases the uptake of other nutrients like $\mathrm{N}$ and $\mathrm{K}$ (Maitra et al., 2008; Lester et al., 2010).

The increase in inorganic (Ca-bound) $\mathrm{P}$ is smaller than that of labile $\mathrm{P}$ and contrasts with the results obtained by Serrasolses et al. (2008), who reported a decrease in the P sorption capacity of acid soils subject to heating and autoclaving. The increase in the inner layer of the soil cover of the 'formiguer' may be explained by the mixture with the ashes from the vegetation pile, which are rich in this form of $\mathrm{P}$ (Romanyà et al., 1994). But the outer layer was not apparently mixed with ashes, and we therefore suggest that part of the mineralized P may have been bound to inorganic surfaces as a result of the decrease in the OC content. In calcareous soils OC acts as a limiting factor of their P sorption capacity (Kordlaghari and Rowell, 2006) and therefore labile P decreases as the OC content decreases (Olarieta et al., 2001, 2004). 
The almost complete loss of mineral $\mathrm{N}$ from both the outer and the inner part of the soil cover as an immediate result of heating suggests that $\mathrm{N}$ was not the nutrient farmers were looking for when building the 'formiguer'. It also falsifies our hypothesis that $\mathrm{N}$ volatilized from the biomass and from the soil would be partly recovered in its passage through the soil cover.

The loss of soil $\mathrm{N}$ in mineral forms would represent a minimum estimate of the total losses of $\mathrm{N}$ from the soil cover, and amounts to $3 \mathrm{~g} \mathrm{~N}$ per 'formiguer' if we assume that the soil cover is equally divided between the inner layer and the outer layer. While the decrease in the total $\mathrm{N}$ content of the soil cover after burning the 'formiguer' is not significant, the difference between the mean values before and after burning represents $17 \%$ of the initial content, or a loss of about $230 \mathrm{~g} \mathrm{~N}$ per 'formiguer', which would set the upper limit to $\mathrm{N}$ losses from the soil cover. Values reported in the literature related to forest fires are in the order of $30-34 \%$ of the total soil $\mathrm{N}$ lost at temperatures of $200-300{ }^{\circ} \mathrm{C}$ (for a brief summary, see Badía and Martí, 2003a).

$\mathrm{N}$ mineralization during incubation shows that the mineral $\mathrm{N}$ content of the soil cover of the 'formiguer' returns to values similar to those of the non-heated soil. $\mathrm{N}$ mineralization potential in similar soils has been shown to increase as the content of mineral $\mathrm{N}$ in the soil decreases (Olarieta et al., 2008a). Therefore, as the 'formiguers' would be burnt in the summer and spread on the agricultural plot just before sowing in October (Mestre and Mestres, 1949; Masip, 2003), the mineral N content in the soil cover would have returned to values similar to those of the non-heated soil as a result of the increased mineralization from organic forms.

But this happens at the expense of the OC in the soil cover, which decreases to about $67 \%$ of the original content and involves a loss of 3.7-6.0 kg of OC per 'formiguer', or a total of 1.0-4.2 Mg C.ha-1 if we assume a total of 260-700 'formiguers' burnt per hectare. This increased mineralization of OC would result from the temperatures reached 
in the 'formiguer' (Fisher and Binkley, 2000), but also from the effect of the smoke produced by the burning biomass (Fischer and Bienkowski, 1999). We

This effect of 'formiguers' in enhancing the mineralization of OC to increase $\mathrm{P}$ availability without decreasing $\mathrm{N}$ availability in the short term would also help explain why similar structures are still used in Southeast Asia as a tool during the clearing phase of the jhum system. The nutrients locked up in the organic matter of the upper mineral horizon during the forest phase may not be completely available for the crops during the few years of the crop phase, and the heating produced by 'formiguer'-like structures would help mineralize them in the short term. The work by Mishra and Ramakrishnan (1983b) shows a significant increase in available $\mathrm{P}$ in soils heated over a burning pile of vegetation just one month after burning.

Further research is needed though to better quantify these changes and to assess the effects of the 'formiguer' on the soil underneath, as the concentration of fuel on a relatively small area and the persistence of heating for a few days may produce effects different from those of a wild fire.

\subsection{Ashes and char}

We could not properly assess the contribution of nutrients from the biomass burnt in the 'formiguer' as we could not quantify nor sample the ashes because the structure of the 'formiguer' collapsed during burning and the ashes mixed with the soil cover. But this fact would confirm the hypothesis of Kerkhoff and Sharma (2006) that 'formiguer'-like structures presently used in Bhutan decrease the loss of nutrients in ashes through convective air currents, which may amount to $55 \%$ of $\mathrm{P}$ and $74 \%$ of $\mathrm{N}$ in the ashes of burnt vegetation (Giardina et al., 2000a).

Nevertheless, our visual field estimate of the amount of ashes and char obtained in the 'formiguer' is of less than $5 \mathrm{~kg}$, which represents a $5 \%$ conversion factor of biomass $\mathrm{C}$ 
to ashes and char $\mathrm{C}$ that is lower than the values of 14-23\% collected by Glaser et al. (2002) for earth kilns. Assuming that those $5 \mathrm{~kg}$ are equally divided into ashes and char, and that their nutrient concentration is that reflected in Table 3, the total amount of nutrients in the ashes and char obtained after burning the 'formiguer' would be $31 \mathrm{~g} \mathrm{~N}, 1-2 \mathrm{~g} \mathrm{P}$, and 5-6 $\mathrm{g} \mathrm{K}$. Considering a number of 260-700 'formiguers' burnt per hectare of agricultural land (Baron de Alvalat, 1780; Roca, 2008), the input of nutrients to the agricultural plot from ashes and char would have been 8-22 kg N, 0.3-0.8 kg P, and 1.5-4.1 kg K.

These figures may look very small, but should be interpreted in context. In the Vallès area (Catalunya), inputs of manure to agricultural plots in 1860-70 were in the range of 3000-4000 kg.ha ${ }^{-1} \cdot \mathrm{y}^{-1}$ (Cussó et al., 2006), which would involve about 12-20 kg N, 2-3 $\mathrm{kg} \mathrm{P}$, and 2-4 kg K. Therefore, burning of 'formiguers', at a density of 260-700 per hectare, would have been similar, in terms of nutrient input, to the application of those rates of manure except for relatively low amounts of P. But as we have previously discussed, a significant flux of labile $\mathrm{P}$ was obtained by enhancing the mineralization of organic forms in the soil cover.

The input of $\mathrm{OC}$, and considering again a total of $5 \mathrm{~kg}$ of equal amounts of ashes and char, would be $650-1750 \mathrm{~kg} \mathrm{C}^{-} \mathrm{ha}^{-1}$. Therefore, the losses of OC incurred in the soil cover as a result of heating would not be compensated by these inputs from ashes and char, and the net loss would amount to $0.35-2.50 \mathrm{Mg} \mathrm{C} \mathrm{ha}^{-1}$.

There are also, of course, issues related to the quality of ashes and char as fertilizers. The short-term availability of the nutrients from ashes and char is low, particularly in the case of P (Carreira and Niell, 1995; Giardina et al., 2000b), although these materials are not so inert as traditionally held, and their influence on the biological (Tryon, 1948; Fischer and Bienkowski, 1999; Pietikäinen et al., 2000; Wardle et al., 2008), physical (Tryon, 1948; Piccolo et al., 1996; Glaser et al., 2002) and chemical (Tryon, 1948; Glaser et al., 2002; Yamato et al., 2006) properties of soils has been proved. 
Nevertheless, the mass of ashes and char from the 'formiguers' would amount to less than $1 \mathrm{~g}^{\mathrm{kg}} \mathrm{kg}^{-1}$ in a $30 \mathrm{~cm}$-soil horizon, which is a much smaller fraction than that represented by the mass of soil affected by heating, $30-80 \mathrm{~g} \cdot \mathrm{kg}^{-1}$ of such soil horizon, even if the effects on the soil underneath the 'formiguer' are not considered. The minor importance of ashes would be consistent with the historical practice in the Atlantic regions of Spain of just burning the soil sods without any pile of vegetation (Miret, 2004). In this region the OC content of soils is higher than in the soils of the Mediterranean region and a higher amount of nutrients would be expected to mineralize in the soil cover of the 'formiguers'. Even in these drier regions, Miret (2004) also suggests that 'formiguers' made only of soil would be burnt if not enough vegetation was available.

\subsection{Land requirement of 'formiguers'}

The land required to provide the biomass burnt in the 'formiguers' depended on the condition and productivity of the forest and shrubland area from where it was collected, but both variables are difficult to assess in relation to historical periods. A cadastral survey of 1859 from a dry region in southwest Catalunya records a 'production' of 65-167 'formiguers' per hectare of forest, depending on the quality of the forest, while historical references in the Vallès area (Roca, 2008) give figures of 520 'formiguers' per hectare of forest. We assume that these evaluations are based on the standing biomass, but in any case they fall short of the 260-700 'formiguers' used per hectare of agricultural land and indicate that a ratio of forest-shrubland/agricultural land of 1.3 was required to obtain the biomass necessary for 'formiguers'. Considering that in the Vallès area in 1860 the ratio of forest and shrubland to agricultural land (excluding vineyards and olive orchards) was just over 3, fertilizing the agricultural land with 'formiguers' would have required harvesting shrubs and small branches from about $40 \%$ of the forest and shrubland area. 
But the relation becomes even more demanding for forests if we consider their above-ground net primary productivity (ANPP). Peñuelas et al. (2007) report an ANPP in shrublands in Catalunya of $1600 \mathrm{~kg} \cdot \mathrm{ha}^{-1} \cdot \mathrm{y}^{-1}$. A similar figure is obtained from the data recorded by Maseyk et al. (2008) in a Pinus halepensis forest considering that only the understory and branches were harvested for 'formiguers'. In this case, about 10-25 ha of forest or shrubland would have been needed to collect enough biomass at a 'sustainable rate' (if we assume this to be equal to their ANPP) to fertilize one hectare of agricultural land with 'formiguers'. In the late 19th century in the Vallès area, a 'sustainable' production of 'formiguers' would have required that forest and shrublands be harvested once every 3-8 years at most.

We have estimated (Olarieta et al., 2008b) that during the second half of the 19th century some 600 ha of forest and shrubland were converted to vineyards in a 3746 hamunicipality in the Vallès area in Catalunya. Such change in land-use was widespread in Spain as the vineyards of France were devastated by the filoxera pest (Daktulosphaira vitifoliae) at the time and Spanish farmers took advantage of the rise in wine prices (BadíaMiró et al., 2010). As stated by Mestre and Mestres (1949), new plantations of vineyards were fertilized with $2 \mathrm{~m}^{3}$-'formiguers', which would have required some $62,400 \mathrm{~kg}$ of biomass per hectare, assuming a density of 260 'formiguers' per hectare of vineyard. Data from Peñuelas et al. (2007) for shrubland and from Alifragis et al. (2001) and Maseyk et al. (2008) for Pinus halepensis forests, suggest that 6,000 kg.ha ${ }^{-1}$ of biomass (branches and/or shrubs) would be available in shrubland and 4,000-5,000 kg.ha-1 of branches and 20,00025,000 kg.ha ${ }^{-1}$ of shrubs in forests. Assuming these values, and furthermore to the complete clearance of the 600 ha transformed into vineyards, branches and shrubs would have been harvested from another 340-410 ha, which represents $21-26 \%$ of the forest and shrubland remaining after the process. Therefore, such processes of land-use change did not only involve a land-use change from forest to vineyard but also the import to these new 
agricultural plots of significant fractions of the stocks of $\mathrm{OC}$ and nutrients stored in the remaining forests.

\subsection{Fate of biochar from 'formiguers'}

Macromorphological descriptions of agricultural soils in Catalunya (northeast Spain) suggest that the present content of biochar in these soils is very low, particularly in the upper mineral horizons. Such descriptions are surely underestimates of the whole content as smaller particles cannot be identified (Nguyen et al., 2008), but still put forward the question of why such scarce presence if 'formiguers' were used up to the 1960's. We

suggest a combination of factors. As previously discussed, 'formiguers' could not have been used on a yearly basis because of the intense pressure they represent for forest areas. Furthermore, the production of biochar in the 'formiguer' is not mentioned at all in the historical references and this may be the result of the small amounts obtained. And even though black carbon is quite stable in acid soils (Glaser et al., 2002; Nguyen et al., 2008), only $30 \%$ remains 30 years after application, and it is expected to be less stable in basic soils (W.I. Woods, pers. comm.). Nevertheless, further research is needed in relation to this issue.

\section{Conclusions}

The short-term fertilizing effect of 'formiguers' in terms of soil nutrients for the agricultural fields was a result of both the input of $\mathrm{K}$ from the ashes and charcoal obtained as a result of burning the piles of vegetation and the increased mineralization of $\mathrm{P}$ in the soil cover as a result of heating. The content of mineral $\mathrm{N}$ in the soil cover of the 'formiguer', although initially depleted, quickly recovers to pre-burning values as a result of the enhanced mineralization of OC. This system of soil fertilization was obtained at the 
expense of soil OC, with net losses of $0.35-2.50 \mathrm{Mg} \mathrm{C}^{-} \mathrm{ha}^{-1}$. The small amounts of ashes and charcoal obtained in what was a popular system of fertilization would be the reason for their low presence in soils today. A significant disturbance of forest and shrublands also resulted from the harvest of the biomass required to burn the 'formiguers'.

\section{Acknowledgements}

This work is part of the research project HAR2009-13748-C03-HIST on "Environmental history of Mediterranean agrarian landscapes" funded by the Spanish Ministry of Science and Innovation. We are very grateful to the reviewers for their insightful comments on a previous version of this paper.

\section{References}

Alifragis, D., Smiris, P., Maris, F., Kavvadias, V., Konstantinidou, E., Stamou, N. 2001. The effect of stand age on the accumulation of nutrients in the aboveground components of an Aleppo pine ecosystem. Forest Ecology and Management 141, 259-269.

Ayoubi, S., Khormali, F., Sahrawat, K.L. 2009. Relationships of barley biomass and grain yields to soil properties within a field in the arid region: use of factor analysis. Acta Agriculturae Scandinavica Section B - Soil and Plant Science 59, 107-117.

Badía, D., Martí, C. 2003a. Plant ash and heat intensity effects on chemical and physical properties of two contrasting soils. Arid Land Research and Management 17, 23-41.

Badía, D., Martí, C. 2003b. Effect of simulated fire on organic matter and selected microbiological properties of two contrasting soils. Arid Land Research and Management 17, 55-69. 
Badía-Miró, M., Tello, E., Valls, P., Garrabou, R. 2010. The grape phylloxera plague as a natural experiment: The upkeep of vineyards in Catalonia (Spain), 1858-1935. Australian Economic History Review 50(1), 39-61.

Barón de Alvalat. 1780. Memoria sobre el cultivo del cañamo en Valencia, por preguntas, y respuestas, leida en Junta de 29 de Abril de 1777. Memorias de la Sociedad Económica (Madrid) 1(14), 110-129.

Carreira, J.A., Niell, F.X. 1995. Mobilization of nutrients by fire in a semiarid gorsescrubland ecosystem of southern Spain. Arid Soil Research and Rehabilitation 9(1), 73-89.

Christiansen, S. 2001. Flows of matter in a traditional heathland farm about 1840. An example from northern West Jutland, Denmark. Danish Journal of Geography 101, 43-66.

Cussó, X., Garrabou, R., Tello, E. 2006. Social metabolism in an agrarian region of Catalonia (Spain) in 1860-1870: flows, energy balance and land use. Ecological Economics 58, 49-65.

Dahlquist, R.M., Prather, T.S., Stapleton, J.J. 2007. Time and temperature requirements for weed seed thermal death. Weed Science 55, 619-625.

de Roxas, S. 1808. Sobre los hormigueros u hornillos. Semanario de Agricultura y Artes del Real Jardín Botánico de Madrid 23(588), 209-216.

Entwistle, J.A., Dodgshon, R.A., Abrahams, P.W. 2000. An investigation of former landuse activity through the physical and chemical analysis of soils from the Isle of Lewis, Outer Hebrides. Archaeological Prospection 7, 171-188.

Fischer, Z., Bienkowski, P. 1999. Some remarks about the effect of smoke from charcoal kilns on soil degradation. Environmental Monitoring and Assessment 58, 349-358.

Fisher, R.F., Binkley, D. 2000. Ecology and Management of Forest Soils, 3rd edition. Wiley, New York. 
Fraterrigo, J.M., Turner, M.G., Pearson, S.M. 2006. Interactions between past land use, life-history traits and understory spatial heterogeneity. Landscape Ecology 21, 777790.

Giardina, C.P., Sanford Jr., R.L., Dockersmith, I.C. 2000a. Changes in soil phosphorus and nitrogen during slash-and-burn clearing of a dry tropical forest. Soil Science Society of America Journal 64(1), 399-405.

Giardina, C.P., Sanford Jr., R.L., Dockersmith, I.C., Jaramillo, V.J. 2000b. The effects of slash burning on ecosystem nutrients during the land preparation phase of shifting cultivation. Plant and Soil 220, 247-260.

Glaser, B., Lehmann, J., Zech, W. 2002. Ameliorating physical and chemical properties of highly weathered soils in the tropics with charcoal - a review. Biology and Fertility of Soils 35, 219-230.

Guzmán, G.I., González de Molina, M. 2009. Preindustrial agriculture versus organic agriculture. The land cost of sustainability. Land Use Policy 26, 502-510.

Ha, K.V., Marschner, P., Bünemann, E.K. 2008. Dynamics of C, N, P and microbial community composition in particulate soil organic matter during residue decomposition. Plant and Soil 303, 253-264.

Kerkhoff, E., Sharma, E. (comps.). 2006. Debating Shifting Cultivation in the Eastern Himalayas. Farmers' Innovations as Lessons for Policy. ICIMOD, Kathmandu.

Koerner, W., Benoît, M., Dambrine, E., Dupouey, J.-L. 1999. Influence des anciennes pratiques agricoles sur la végétation et les sols des forêts reboisées dans le Massif vosgien. Revue Forestière Française LI(2), 231-238.

Kordlaghari, M.P., Rowell, D.L. 2006. The role of gypsum in the reactions of phosphate with soils. Geoderma 132(1-2), 105-115.

Lehmann, J., Gaunt, J., Rondon, M. 2006. Bio-char sequestration in terrestrial ecosystems a review. Mitigation and Adaptation Strategies for Global Change 11, 403-427. 
Lester, D.W:, Birch, C.J., Dowling, C.W. 2010. Fertiliser N and P application on two Vertosols in north-eastern Australia. 3. Grain N uptake and yield by crop/fallow combination, and cumulative grain $\mathrm{N}$ removal and fertiliser $\mathrm{N}$ recovery in grain. Crop \& Pasture Science 61, 24-31.

Masip, G. 2003. Els Agroecosistemes Tradicionals de la Bisbal de Falset. MSc Thesis. Universidad Internacional de Andalucía, Baeza.

Madari, B., Benites, V. de M., Cunha, T.J.F. 2003. The effect of management on the fertility of Amazonian Dark Earth soils, in: Lehmann J. et al. (Eds.), Amazonian Dark Earths: Origin, Properties, Management. Kluwer, Dordrecht, pp. 407-432.

Maitra, D.N., Sarkar, S.K., Saha, S., Tripathi, M.K., Majumdar, B., Saha, A.R. 2008. Effect of phosphorus and farmyard manure applied to sunhemp (Crotolaria juncea) on yield and nutrient uptake of sunhemp-wheat (Triticum aestivum) cropping system and fertility status in a Typic Ustocrept of Uttar Pradesh. Indian Journal of Agricultural Sciences 78(1), 70-74.

Maseyk, K., Grünzweig, J.M., Rotenberg, E., Yakir, D. 2008. Respiration acclimation contributes to high carbon-use efficiency in a seasonally dry pine forest. Global Change Biology 14, 1553-1567.

Matons, A. 1917-18. Els formiguers. Un costum absurd. Agricultura, Revista Agricola Catalana 1, 3-6.

Mestre, C., Mestres, A. 1949. Aportación al Estudio de la Fertilización del Suelo por Medio de Hormigueros. Cuaderno 109. Estación de Viticultura y Enología de Villafranca del Panades, INIA, Ministerio de Agricultura, Madrid.

Miret, J. 2004. Las rozas en la Península Ibérica. Apuntes de tecnología agraria tradicional. Historia Agraria 34, 165-193. 
Mishra, B.K., Ramakrishnan, P.S. 1983a. Slash and burn agriculture at higher elevations in north-eastern India. I. Sediment, water and nutrient losses. Agriculture, Ecosystems and Environment 9, 69-82.

Mishra, B.K., Ramakrishnan, P.S. 1983b. Slash and burn agriculture at higher elevations in north-eastern India. II. Soil fertility changes. Agriculture, Ecosystems and Environment 9, 83-96.

Nguyen, B.T., Lehmann, J., Kinyangi, J., Smernik, R., Riha, S.J., Engelhard, M.H. 2008. Long-term black carbon dynamics in cultivated soils. Biogeochemistry 89, 295-308.

Olarieta, J.R., Molins, J., Rodríguez, R., Blanco, R., Antúnez, M. 2001. Aproximación a los requerimientos del territorio para el crecimiento de pino silvestre (Pinus sylvestris L.) en la Sierra de Odén (Lleida). Edafología 8(2), 13-20.

Olarieta, J.R., Sempere, S., Rodríguez-Ochoa, R., Usón, A. 2004. Aproximación a los requisitos del territorio para el crecimiento de Pinus halepensis en la Serra de Montsant (Tarragona). Cuadernos de la Sociedad Española de Ciencias Forestales 20, 99-104.

Olarieta, J.R., Lizano, J., Rodríguez-Ochoa, R., Alcarria, Z. 2008a. Efectos de un incendio sobre diversas propiedades físico-químicas del suelo y procesos de erosión hídrica en medio semiárido (La Granja d'Escarp, Lleida). Cuadernos de la Sociedad Española de Ciencias Forestales 25, 345-350.

Olarieta, J.R., Rodríguez-Valle, F.L., Tello, E. 2008b. Preserving and destroying soils, transforming landscapes: soils and land-use change in the Vallès County (Catalunya, Spain) 1853-2004. Land Use Policy 25, 474-484.

Peñuelas, J., Prieto, P., Beier, C. et al. 2007. Response of plant species richness and primary productivity in shrublands along a north-south gradient in Europe to seven years of experimental warming and drought: reductions in primary productivity in the heat and drought year of 2003. Global Change Biology 13, 2563-2581. 
Piccolo, A., Pietramellara, G., Mbagwu, J.S.C. 1996. Effects of coal-derived humic substances on water retention and structural stability of Mediterranean soils. Soil Use and Management 12, 209-213.

Pietikäinen, J., Kiikkilä, O., Fritze, H. 2000. Charcoal as a habitat for microbes and its effect on the microbial community of the underlying humus. Oikos 89, 231-242.

Roca, P. 2008. El Sistema Cereal de Secà i la Ramaderia a les Masies del Vallès Occidental entre els Segles XVII i XIX. Treball de Recerca. Programa Interuniversitari de Doctorat en Història Econòmica de la Universitat de Barcelona i la Universitat Autònoma de Barcelona, Bellaterra.

Romanyà, J., Khanna, P.K., Raison, R.J. 1994. Effects of slash burning on soil phosphorus fractions and sorption and desorption of phosphorus. Forest Ecology and Management 65, 89-103.

Saguer, E., Garrabou, R. 1996. Métodos de fertilización en la agricultura catalana durante la segunda mitad del siglo XIX. Una aproximación a los procesos físicos de reposición de la fertilidad agrícola, in Garrabou, R., Naredo, J.M. (Eds.), La Fertilización en los Sistemas Agrarios. Una Perspectiva Histórica. Argentaria, Visor, Madrid, pp. 89-126.

Serrasolses, I., Khanna, P.K. 1995. Changes in heated and autoclaved forest soils of S.E. Australia. I. Carbon and nitrogen. Biogeochemistry 29, 3-24.

Serrasolses, I., Romanyà, J., Khanna, P.K. 2008. Effects of heating and autoclaving on sorption and desorption of phosphorus in some forest soils. Biology and Fertility of Soils 44, 1063-1072.

Tello, E., Garrabou, R., Cussó, X., Olarieta, J.R. 2008. Una interpretación de los cambios de uso del suelo desde el punto de vista del metabolismo social agrario. La comarca catalana del Vallès, 1853-2004. Revista Iberoamericana de Economía Ecológica 7, $97-115$. 
Tryon, E.H. 1948. Effect of charcoal on certain physical, chemical, and biological properties of forest soils. Ecological Monographs 18(1), 81-115.

Valkama E., Uusitalo, R., Ylivainio, K., Virkajärvi, P., Turtola, E. 2009. Phosphorus fertilization: a meta-analysis of 80 years of research in Finland. Agriculture, Ecosystems and Environment 130, 75-85.

Wardle, D.A., Nilsson, M.-C., Zackrisson, O. 2008. Fire-derived charcoal causes loss of forest humus. Science 320, 629.

Woods, W.I. 2003. Development of Anthrosol research, in: Lehmann, J. et al. (Eds.), Amazonian Dark Earths: Origin, Properties, Management. Kluwer Academic, Dordrecht, pp. 3-14.

Yamato, M., Okimori, Y., Wibowo, I.F., Anshori, S., Ogawa, M. 2006. Effects of the application of charred bark of Acacia mangium on the yield of maize, cowpea and peanut, and soil chemical propeties in South Sumatra, Indonesia. Soil Science \& Plant Nutrition 52(4), 489-495. 